\title{
ASSESSMENT OF THE LEVEL OF CONSTANTITY OF SUPPLY CHAINS OF INDUSTRIAL ENTERPRISES OF UKRAINE
}

\author{
Kateryna Kitrish ${ }^{1}$
}

\begin{abstract}
Industry plays a crucial role in solving current problems, namely: the accelerated development of industry, is a generator of scientific and technological progress and innovation, an important factor in the global competitiveness of national economies and a driver of economic growth. Therefore, increasing attention to the development of industry and industrial policy is one of the main trends in the modern world economy. The purpose of the paper - to analyze the sustainable development of industrial enterprises of Ukraine from the standpoint of security, using a system-structural approach. Methodology. The concept of sustainable development is a management structure that contains a general system view of the ways of transition from the current position of the object of management to the desired, includes the following steps: defining the structure of sustainable development; defining the boundaries of safe existence; identification of the level of sustainability of supply chains; identification of imbalances of sustainable development; to substantiate the methodical approach to estimating the level of sustainability of supply chains of industrial enterprises with the use of economic and mathematical tools; determining the impact of threats and developing institutional measures. The results of the study revealed disparities in sustainable development at the level of economic, social and environmental security of the enterprise, at the level of subordinate components and at the level of indicators that determine the list of major threats, which are calculated indicators of social and economic components of sustainable development. To determine the severity of the impact of threats, the coefficients of elasticity of each component and indicator on the integrated index of sustainable development were calculated and ranked, which is the necessary information for the development of priority measures. Practical implications. The dynamics of deviations of current values of integrated indices from their average optimal values determines the importance of threats to the components of sustainable development. Almost all of these industrial enterprises are characterized by complete neglect of the social status of employees, which inhibits economic growth and makes it impossible to develop domestic demand. Under such conditions, the issue of digitalization of business becomes relevant. The digitalization of business has received considerable attention from both academia and the business community, which define digitalization as a focused effort of companies to actively use digital technologies at all levels to optimize internal processes and modify the overall business model. Value/originality. The obtained strategic guidelines of key macro indicators, which together with the strategic values of indicators are the ultimate goal of sustainable development regulation, which can be monitored through monitoring to monitor the implementation of the Development Strategy and evaluate the policy of enterprise management.
\end{abstract}

Key words: industrial enterprise, supply chain, supply chain management, sustainability, economic security, indicator, stimulator, disincentive, sustainable development, methodological approach, evaluation, macroindicator.

\section{JEL Classification: O14, L61, L23}

\section{Introduction}

An important role of scientific and technological progress and innovation in industry is given in the UN report, without which the process of industrialization is impossible, which, in turn, hinders development. On the one hand, technology makes the production process more efficient, thereby increasing the competitiveness of countries and reducing their vulnerability due to market fluctuations. On the other hand, economic growth entails an increase in the use of resources, materials and fossil fuels, which leads to pollution and environmental degradation,

Corresponding author:

${ }^{1}$ Institute of Industrial Economics of the National Academy of Sciences of Ukraine, Ukraine.

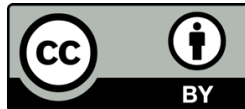

E-mail: ekaterina.kitrish@gmail.com

ORCID: https://orcid.org/0000-0002-5363-7609

This is an Open Access article, distributed under the terms of the Creative Commons Attribution CC BY 4.0 
especially in low-income countries. Therefore, if countries do not take steps in all three areas and reach compromises between them: support economic growth, promote social development and strive for environmental sustainability - it is unlikely that such countries will go far on the path to sustainable progress, regardless of their level. development. Therefore, a balanced development is extremely necessary, taking into account the limitations in all three areas. The issue of supply chain management over the last decade has been widely reflected in the economic literature. Well-known foreign scientists such as Bauersocks D., Christopher M., Waters D., Stoke J. and Lambert D. pay considerable attention to their study from the standpoint of logistics. Among domestic scientists it is worth noting, first of all, the works of Krykavsky E.V., Nikolaychuk V.E., Oklander A.M., Chukhray N.I., Grigorak M.Yu. The topic of the impact of digitalization and digital technologies on the business model in general has been considered in the works of many scientists, among whom G. Bowman, A. Osterwalder, V. Apalkova, S. Volosovych, L.G. Melnyk, A.I. Karintseva and V. Pleskach, in whose works the processes of digitalization of the economy are studied. The digital economy as the latest vector of reconstruction of the traditional economy was considered in the works of Putzenteilo P., Humeniuk O., Sirko A., Kirilov Y., Granovska V., Krikunova V. and others.

According to foreign experience, modern industry is a generator of scientific and technological progress and innovation in the economy.

The structure and system of indicators of sustainable development of industrial enterprises from the standpoint of safety, which includes the following components of economic, social and environmental security: economic status, financial condition, business risks, labor relations, safety and health, waste management, energy status - in general 25 indicators related to stimulants and destimulators.

\section{Components and indicators of sustainable development of industrial enterprises}

The structure of sustainable development of an industrial enterprise includes a number of interconnected structural elements that reflect certain areas of activity of an industrial enterprise in the supply chain.

The presence of economic, social and environmental security in the structure of sustainable development of an industrial enterprise is due to modern trends in understanding sustainable development, which is associated with such economic growth, material production and other activities, when they occur within the limits determined by the ability of ecosystems and to support the livelihoods of present and future generations.
It is this requirement - the observance of the limits of safe existence of dynamic systems - that unquestionably connects the problem of sustainable development with the problem of economic security, the main task of which is to compare the components of development with thresholds, which translates "development" into "security". This approach allows the use of methodological tools for identification and strategy, tested in economic security, for the needs of sustainable development of industrial enterprises (Kharazishvili, 2020).

Each component of the first level (economic, social, environmental) has components of the second level with the corresponding indicators. The number of levels of subordination depends on the degree of formalization of the group of indicators. Thus, for the components of the first level, the following subordinate components and indicators are defined (Table 1), divided into stimulants (increase of which is desirable) and destimulators (decrease of which is desirable). The diversity of their action is reduced to unidirectional through the procedure of normalization of indicators.

To determine the threshold values of development indicators, it is proposed to use the following methods (the list is based on their priority):

- functional dependencies (macro- / microeconomic analytical or statistical equations; Akhiezer-Goltz; information theory; "golden section");

- macroeconomic models that adequately reflect the effects of destabilizing factors on the conditions of a particular country in the current period;

- stochastic (t-test; diagnosis: cluster analysis, fuzzy sets; logistic regression);

- nonlinear dynamics (Wavelet analysis);

- legislative approach (setting thresholds at the legislative level);

- heuristic ("snowball"; analog approach - focus on indicators of analogue countries; "calibration");

- expert assessments; taking into account the assessments of international organizations.

To determine the vector of threshold values of industrial indicators, we will use the most accessible method of "t-test", which consists in constructing the probability density function, calculation of statistical characteristics (mathematical expectation, standard deviation and asymmetry) and formalized calculation of the threshold vector. According to the results of the analysis of the diversity of indicators, three characteristic types of distribution were revealed: normal, lognormal and exponential, for which a formalized definition of the vector of threshold values was proposed, where $\propto-$ average value, $\sigma$ - standard deviation, $t-$ taken from Student's $\mathrm{t}$-distribution tables:

normal:

lower threshold $=\mu-t \cdot \sigma$; upper threshold $=\mu+t \cdot \sigma$. 
Table 1

Components and indicators for assessing the level of sustainability of supply chains

\begin{tabular}{|c|c|c|}
\hline Components & Indicators & The nature of the impact \\
\hline $\begin{array}{l}\text { 1. Economic: } \\
\text { 1.1. Economic condition }\end{array}$ & $\begin{array}{l}\text { - the share of the enterprise in the domestic market of products supplied in the supply } \\
\text { chain, \%; } \\
\text { - price competitiveness (the ratio of average market price and product price of the } \\
\text { enterprise); } \\
\text { - the level of manufacturability of production (the ratio of gross value added to output); } \\
\text { - level of investment (ratio of capital investment to output), \%; } \\
\text { - the level of renewal of fixed assets, \% }\end{array}$ & $\begin{array}{l}\text { Stimulator } \\
\text { Stimulator } \\
\text { Stimulator } \\
\text { Stimulator } \\
\text { Stimulator }\end{array}$ \\
\hline 1.2. Financial position & $\begin{array}{l}\text { - return on capital of the enterprise, } \% \\
\text { - financial independence (share of own sources in the liabilities of the enterprise), \%; } \\
\text { - absolute liquidity of the enterprise at the time of evaluation, } \% \text {; }\end{array}$ & $\begin{array}{l}\text { Stimulator } \\
\text { Stimulator } \\
\text { Stimulator }\end{array}$ \\
\hline 1.3. Risk in the enterprise & $\begin{array}{l}\text { - the level of non-compliance of product quality, (the volume of products returned to } \\
\text { the company and which received complaints on quality parameters in relation to the } \\
\text { total sales for the analyzed period), \%; } \\
\text { - depreciation rate of the active part of fixed assets, } \% \text {. }\end{array}$ & Disincentive \\
\hline $\begin{array}{l}\text { 2. Social: } \\
\text { 2.1. Labor relations }\end{array}$ & $\begin{array}{l}\text { - the share of wages in the issue; } \\
\text { - the ratio of the average at the enterprise and the official minimum wage; } \\
\text { - the share of workers covered by the collective agreement to the total number of } \\
\text { employees of the enterprise; } \\
\text { - costs of the enterprise for social purposes in relation to the annual output, \%; }\end{array}$ & $\begin{array}{l}\text { Stimulator } \\
\text { Stimulator } \\
\text { Stimulator } \\
\text { Stimulator }\end{array}$ \\
\hline 2.2. Safety and health; & $\begin{array}{l}\text { - level of occupational injuries, \%; } \\
\text { - loss of working time due to illness of employees, \% to the regulatory fund of } \\
\text { working time; } \\
\text { - share of employees laid off voluntarily due to unsatisfactory production conditions, } \\
\% \text { of the number of employees; } \\
\text { - specific weight of jobs that do not meet the established sanitary and hygienic norms, } \\
\% \text { to the number of people employed in production }\end{array}$ & $\begin{array}{l}\text { Disincentive } \\
\text { Disincentive } \\
\text { Disincentive } \\
\text { Disincentive }\end{array}$ \\
\hline $\begin{array}{l}\text { 3. Environmental } \\
\text { 3.1. Waste management }\end{array}$ & $\begin{array}{l}\text { - the level of emissions of pollutants into the atmosphere, per } 1 \text { thousand UAH of } \\
\text { production; } \\
\text { - the level of generated solid production waste per } 1 \text { thousand UAH of production } \\
\text { volume, } \mathrm{kg} / \text { thousand UAH; } \\
\text { - level of disposed production waste per } 1 \text { ton of production volume, } \mathrm{t} / \mathrm{t} \text {; } \\
\text { - level of discharge of polluted water into surface water bodies, per } 1 \text { ton of } \\
\text { production volume, thousand } \mathrm{m}^{3} / \mathrm{t} \text {; } \\
\text { - level of harmful substances in effluents, to the total volume of effluents, } \\
\mathrm{kg} / \text { thousand } \mathrm{m}^{3} \text {; }\end{array}$ & $\begin{array}{l}\text { Disincentive } \\
\text { Disincentive } \\
\text { Disincentive } \\
\text { Disincentive } \\
\text { Disincentive }\end{array}$ \\
\hline 3.2. Energy state & $\begin{array}{l}\text { - level of total energy consumption, UAH per } 1 \text { ton of production volume; } \\
\text { - the level of exceeding the established norms of total consumption of drinking and } \\
\text { technical water by UAH } 1,000 \text {. production volume, times. }\end{array}$ & $\begin{array}{l}\text { Disincentive } \\
\text { Disincentive }\end{array}$ \\
\hline
\end{tabular}

Source: compiled by the author

lower optimal $=\mu+\sigma$; upper optimal $=\mu-\sigma$;

lognormal:

lower threshold $=\mu-t \cdot \sigma / k_{a s}$; upper threshold $=$ $\mu+t \cdot \sigma$;

lower optimal $=\mu-\sigma / k_{a s} ;$ upper optimal $=\mu+\sigma$;

exponential:

lower threshold $=\mu-\sigma / k_{\text {as }}$; upper threshold $=$ $\mu+t \cdot \sigma$;

lower optimal $=\propto$; upper optimal $=\mu+\sigma$.

Similar data from EU countries, regions of Ukraine and industrial enterprises of Ukraine were used to determine the vector of threshold values, and in the absence of such data - expert estimates (Kitrish, 2021). For specific indicators, the countries, regions or enterprises that have the best values of the relevant indicators and can be a promising model were selected. Choosing the same list of countries, regions and businesses and the same time period is desirable, but not always possible. A similar opinion is expressed by Libanova: "During the development of the hypothesis should take into account not only the existing trends of their country, but also the parameters of their development in other countries, especially those that can serve as a benchmark for Ukraine" (Libanova, 2014). Thus, the definition of the vector of threshold values is similar to the construction of a hypothetical enterprise with the highest level of sustainable development for all indicators. 


\section{Integral assessment of the level of sustainable development of industrial enterprises from the standpoint of economic security}

Due to the fact that each indicator has its impact in a dynamic system and may increase or decrease in individual periods, it is necessary to determine the assessment of the system as a whole, taking into account all existing factors - ie integrated assessment of the system. In itself, determining the dynamics of integrated indices means nothing but a decrease / increase in certain periods. To determine the state of security of system development, it is necessary to compare the dynamics of integrated indices with integrated threshold values on the same scale - namely the identification of the state of the system. Problems of internal development of Ukraine's economy, dynamic changes in the global economic space and increasing the degree of openness of the national economy require improvement of the methodology for identifying the level of economic security in order to adequately respond to destabilizing factors.

Thus, first, it is difficult to overestimate the importance of the stage of identifying the level of economic security. Second, the strategic vision of sustainable development first involves establishing the distance from it at which the social, economic and environmental components are located. That is, it is advisable to determine the starting point for each component of sustainable (socio-ecologicaleconomic) development, on which depends its strategic vision, and then - to apply theoretical approaches to justify the strategic guidelines for achieving sustainable development.

Therefore, the importance of economic security assessments of any level is unquestionable, such assessments are the basis for decisions not only on economic security, but also opportunities for system development, determining the necessary resources, creating and using system reserves, assessing the effectiveness of economic security and division of the enterprise.

To date, there are several noteworthy approaches to integrated assessment of the level of economic security:

- at the official level, the approach of the Ministry of Economic Development and Trade (for the macro level) and the State Statistics Service of Ukraine (for the regional level);

- at the informal level, the approach of the National Institute for Strategic Studies and its further development of the Institute of Industrial Economics of the National Academy of Sciences of Ukraine.

In 2013, the National Institute for Strategic Studies published a scientific-analytical note, which substantiated the shortcomings of the methodological approaches proposed by MEDT and the State Statistics
Service of Ukraine, the main of which relate to the list of indicators, expert determination of weights, forms of integrated index, activities, rationing methods, the impossibility of comparing the dynamics of integrated indices with integrated threshold values (because they are not calculated). The biggest drawback is the definition of the generalized integral index as the arithmetic mean of the values calculated by two methods of indicator normalization (the first in one scale range, the second - in five scale ranges), which is not mathematically correct and similar to adding correct fractions without bringing them to a common denominator. This disadvantage makes it almost impossible to use such approaches.

The identified shortcomings indicate the need to improve formal methodological approaches to assessing the level of economic security and the level of socio-economic development. In accordance with the Regulation on the Ministry of Economic Development and Trade of Ukraine by the order of the President of Ukraine dated 29.10.2013 № 1277 the previous Methodology was repealed and new Methodological recommendationswere approved, which are informative, recommendatory, explanatory and optional (according to authors of Methodical recommendations).

In 2014, the National Institute for Strategic Studies published an article in the journal "Economy of Ukraine", which conducted a detailed analysis and attempt to apply new guidelines, which revealed new comments on the types of indicators, rationing methods, determination of weights.

The main remarks about the new MEDT Methodology, which complicate or make its use impossible, are as follows:

- the choice of five ranges of economic security relative to some optimal value is subjective and unreasonable; - artificial "trimming" of indicators during rationing, which leads to loss of information;

- switching of the mixed type of indicator "stimulatorde-stimulator "and the scale of rationing violates continuity the functions of the normalized indicator and, accordingly, the integrated index, which makes it impossible to use optimization methods to adjust the ECB level by calculating the gradient of the integral index function;

- in case of using the proposed rationing methods, including 5 ranges and insensitivity zone, the transition from normalized values of indicators to their initial dimension is also ambiguous - one normalized value of the indicator corresponds to more than one value of the original indicator in natural units, which makes it impossible to apply this technique for strategizing;

- expert determination of weights, which contains subjectivism and, of course, reduces the scientific and practical value of the results;

- consistency of weights throughout the analyzed period, which does not correspond to reality; 
Table 2

Vector thresholds for sustainable development *

\begin{tabular}{|l|c|c|c|c|}
\hline \multicolumn{1}{|c|}{ Indicators } & Lower threshold & The bottom is optimal & The upper is optimal & Upper threshold \\
\hline Economic security & 0,3173 & 0,5841 & 0,7697 & 0,9694 \\
\hline Social security & 0,5507 & 0,7434 & 0,8658 & 0,9753 \\
\hline Ecological safety & 0,5620 & 0,6893 & 0,7793 & 0,8729 \\
\hline Sustainability & 0,4606 & 0,6697 & 0,8055 & 0,9404 \\
\hline
\end{tabular}

Source: author's calculation

- lack of simultaneous definition of integrated indices and integrated thresholds, which does not allow to identify the security level.

To determine the dynamics of integrated indices of sustainable development, integrated threshold values were calculated through the integrated convolution of threshold values of economic, social and environmental security of industrial enterprises of Ukraine (Table 2).

The following convolution of the main components of sustainable development allows to obtain integrated indices of sustainable development of industrial enterprises as a whole, which comprehensively reflect the current state of sustainable development (Figure 1).

$$
I_{c p, t}=I_{\text {eкон }, t}^{a_{1, t}} I_{c o u, t}^{a_{2, t}} \cdot I_{\text {eкол, },}^{a_{3, t}} .
$$

where $I_{c p, t}$ - integrated index of sustainable development;

$I_{\text {екон, }}$ - integrated index of economic development;

$I_{c o u, t}^{a_{1, t}}-$ integrated index of social development;

$I_{\text {eкon, } t}^{a_{2, t}}$ - integrated index of ecological development;

$a_{1, t}, a_{2, t}, a_{3, t}$ - dynamic weights.

According to calculations, the level of sustainable development of industrial enterprises is extremely unsatisfactory and is in a critical zone - below the lower threshold, and Azovstal is the best among the worst industrial enterprises in the last 2 years. The worst of the worst is Arcelor-Mittal. The data obtained indicate a failed economic, social and environmental policy.

The vectors of the integrated threshold values of the components of sustainable development differ significantly, which indicates different proximity (disproportionate development) of the integrated indices to the average optimal value for each component of sustainable development, which can be considered criteria for achieving sustainable development (Figures 2-5).

Under such conditions, the issue of digitalization of business becomes relevant. The digitalization of business has received considerable attention from both academia and the business community, which define digitalization as a focused effort of companies to actively use digital technologies at all levels to optimize internal processes and modify the overall business model (UNECE, 2012; 2013).

\section{Findings}

The structure and system of indicators of sustainable development of industrial enterprises from the point of view of safety was developed, which includes the following components of economic, social and environmental security: economic condition, financial condition, business risks, labor relations, safety and health, waste management,

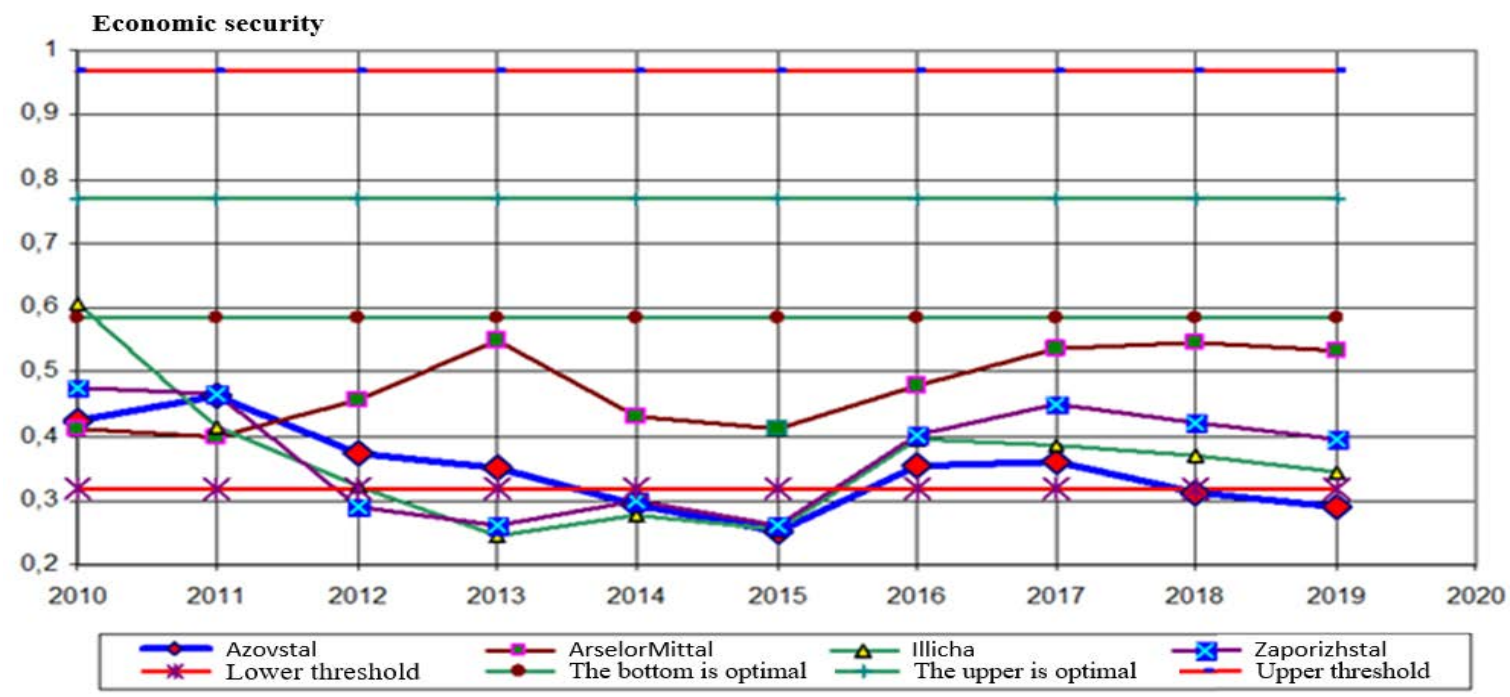

Figure 1. Dynamics of integrated indices of sustainable development of industrial enterprises of Ukraine 
Vol. 2 No. 3, 2021

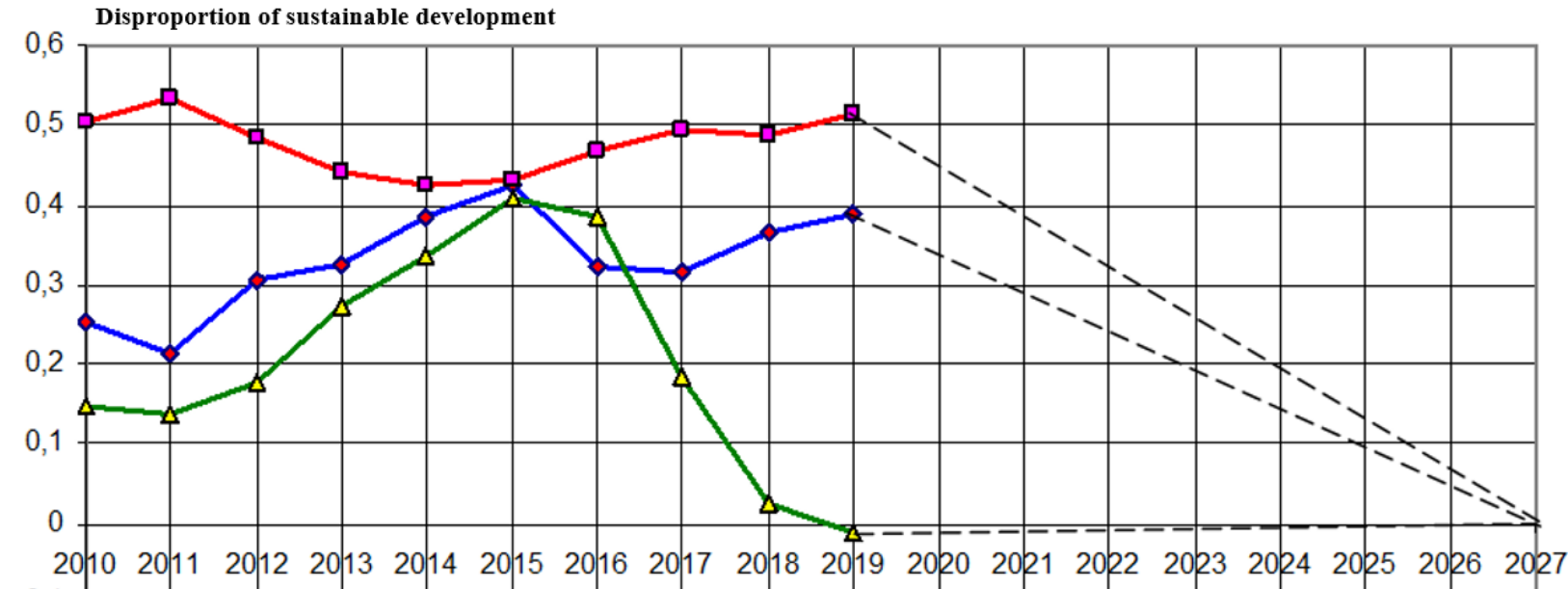

$-0,1$

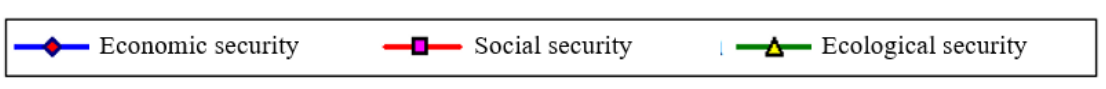

Figure 2. Disproportion of components of sustainable development of the industrial enterprise Azovstal

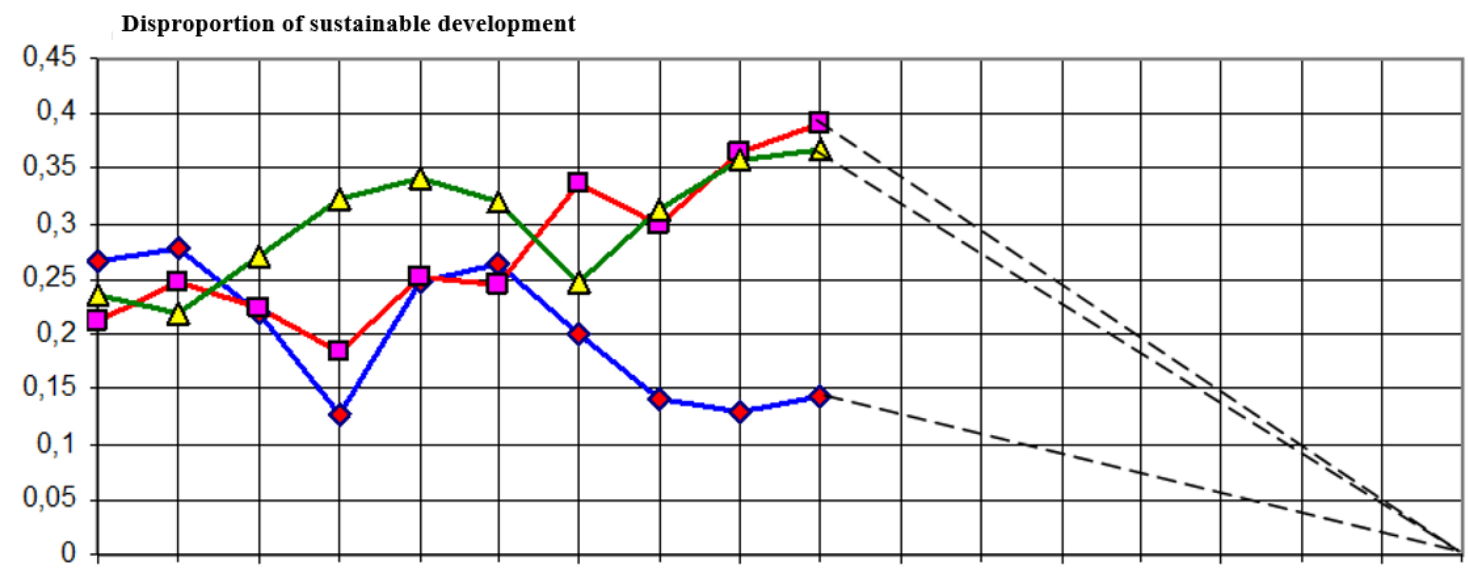

201020112012201320142015201620172018201920202021202220232024202520262027

$\neg$ Economic security $\rightarrow$ - Social security $\quad \longrightarrow$ Ecological security

Figure 3. Disproportion of the components of sustainable development of the industrial enterprise ArcelorMittal

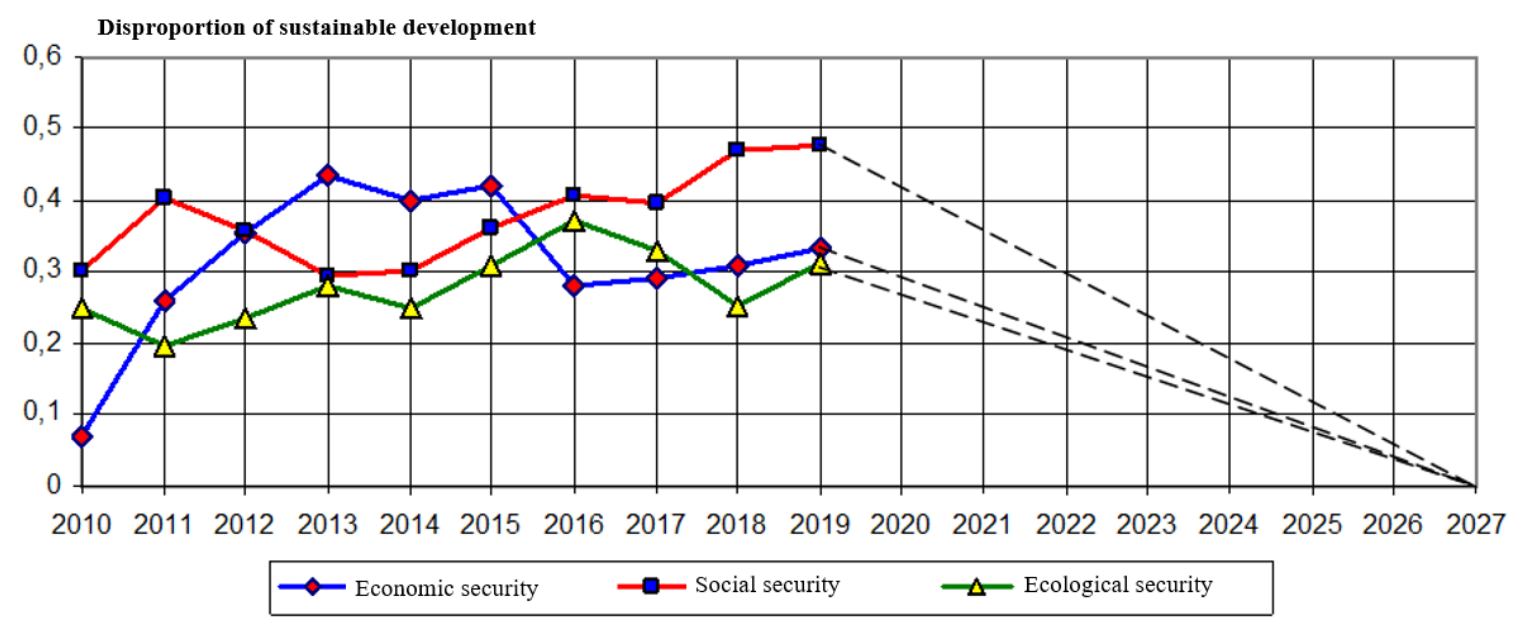

Figure 4. Disproportion of components of sustainable development of Ilyich's industrial enterprise 


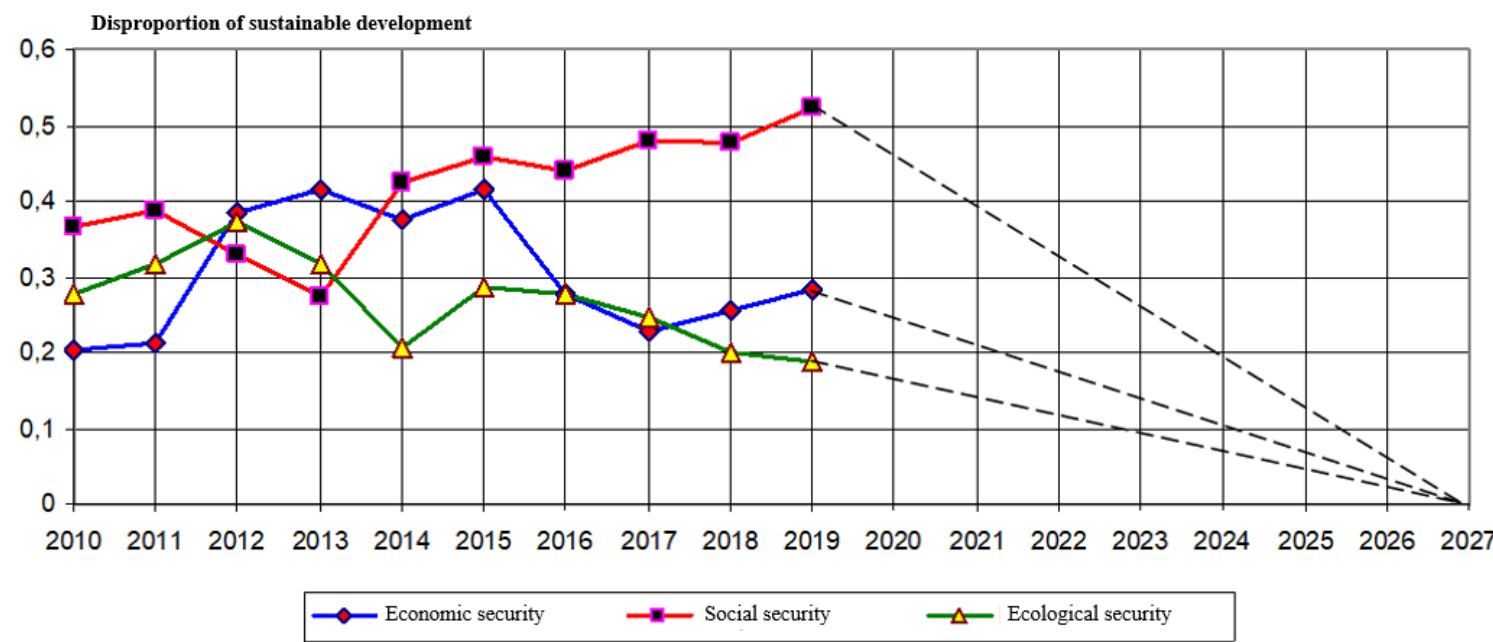

Figure 5. Disproportion of components of sustainable development of industrial enterprise Zaporizhstal

energy status - a total of 25 indicators related to stimulants and disincentives.

The dynamics of deviations of current values of integrated indices from their average optimal values determines the importance of threats to the components of sustainable development. Almost all of these industrial enterprises are characterized by complete neglect of the social status of employees, which inhibits economic growth and makes it impossible to develop domestic demand.

\section{Conclusions}

The main task of any development strategy is to get an answer to the question: what should be the indicators and relevant macro indicators to achieve the desired level of development? Unfortunately, most existing strategies and relevant publications on this topic are limited to general declarations such as: provide, enhance, create, shape, update, implement, improve, engage, develop, and so on. without scientific substantiation of target strategic guidelines.

In recent years, more and more companies are focusing on environmental, social and management initiatives (ESGs) led by key investors and stakeholders. This encourages organizations not only to reevaluate the methods by which they measure and communicate their risk, compliance, sustainability, and management effectiveness, but also how ESGs can be incorporated into their culture to meet their organizational responsibilities.

Over the years, digital transformation has become a basic need for all companies. Investing in technology solutions, both to automate operational processes and to improve team performance, is so crucial that it can even determine the success of companies in the current scenario, characterized by high investment in innovation to improve processes and attract the attention of an increasingly demanding audience.
Also in this context of digital travel, the concept of ESG (environment, social security and governance) has also gained popularity - an indicator that measures companies according to their impact on these three axes of sustainable development. Constant changes in the profile of the public, as well as society as a whole, put pressure on companies to take unprecedented action in the development of their services and products. As a result, Digital Transformation and ESG have taken the lead in discussing new management models. One area of business models is the blockchain.

In addition to digital travel, ESG is a necessary transformation that goes hand in hand with digitization. Therefore, the connection of both allows for more strategic and profitable actions for both organizations and society as a whole.

From industrial and mining companies, customers are increasingly demanding information on metals and raw materials:

1. Origin: From which mines / mining companies do they get the minerals and metals contained in their final products?

2. Production methods: what methods are they produced? Are they produced responsibly?

Blockchain technology has the potential to meet the above requirements within robust supply chain systems. Blockchain is a technology that allows you to check data and then store it as a fixed "block" in a distributed digital database. The resulting chain of blocks is unchanged, because each block is checked on the basis of previous blocks, which makes it very difficult for the snake, because changing the recorded transaction requires changing all previous blocks. The blocks are checked either by an algorithm or by a third party.

In further research, attention should be paid to the environmental component, namely the development of green solutions, the implementation of which will contribute to the transformation of supply chains of industrial enterprises. 


\section{References:}

Akoff, R. (2002). O menedzhmente [About Management]. Sankt-Peterburg: Piter. (in Russian)

Dotsenko, I. O. (2017). Formuvannja systemy ocinjuvannja rivnja ekonomichnoji bezpeky pidpryjemstva z urakhuvannjam vplyvu pidpryjemnycjkykh ryzykiv [Formation of a system for assessing the level of economic security of the enterprise, taking into account the impact of business risks]. Visnyk Odeskoho natsionalnoho universytetu. Ekonomika, 18(1), 69-78. Available at: http://nbuv.gov.ua/j-pdf/Vonu_econ_2013_18_1_10.pdf (accessed 11 August 2021).

Druker, P. (2008). Effektivnoe upravlenie predpriyatiem [Effective enterprise management]. Moscow: Vil'yams. (in Russian)

Fridman, A. (2020). Borot'ba za dushu hlobal'noyi ekonomiky [Struggle for the soul of the global economy]. Available at: https://nv.ua/ukr/opinion/maybutnye-zaraz-prognoz-dlya-svitovoji-ekonomiki-na-2020-rikostanninovini-50072520.html (accessed 5 May 2021).

Heymann, E., \& Vetter, S. (2013). Europe's re-industrialisation. The gulf between aspiration and reality. Frankfurt am Main: Deutsche Bank AG, DB Research.

Hrishnova, O. A. (2011). Sotsialno-ekonomichni ta demohrafichni naslidky systemnoyi kryzy v Ukrayini ta shlyakhy yikh podolannya [Socio-economic and demographic consequences of the systemic crisis in Ukraine and ways to overcome them]. Available at: https://dse.org.ua/arhcive/15/3.pdf

Hurzhii, N. M. (2011). Systema marketynghovykh ryzykiv u dijaljnosti pidpryjemstva [System of marketing risks in the activity of the enterprise]. Visnyk Khmelnytskoho natsionalnoho universytetu, 6(4), 167-170. (in Ukrainian)

Kitrish, K. Yu. (2021). Stalist yak chynnyk upravlinnia lantsiuhamy postachan [Sustainability as a factor in supply chain management]. Infrastruktura rynku, 51, 141-148.

Kharazishvili, Ju. M. (2020). Systemna bezpeka stalogho rozvytku: instrumentarij ocinky, rezervy ta strateghichni scenariji realizaciji [System security of sustainable development: evaluation tools, reserves and strategic implementation scenarios]. Kyiv: National Academy of Sciences of Ukraine, Institute for the Economy of Industry. (in Ukrainian)

Kryvovyazyuk, I. V. (2013). Innovative approach to security assessment in industrial enterprises functioning. Aktualni problemi ekonomiki, 3(141), 83-95.

Martunyuk Olena (2017). Methodology for Diagnostics of the Company Management and Technological Maturity. International economics journal Montenegrin Journal of Economics, vol. 13, no. 4, pp. 31-42. Available at: http://www.mnje.com/sites/mnje.com/files/031-042_martynyuk.pdf

Novikova, M. (2016). Mekhanizm upravlinnja loghistychnymy vytratamy na promyslovomu pidpryjemstvi [Mechanism for managing logistics costs in an industrial enterprise]. Sumy: SSU.

Oleksiv, I. (2014). Theoretical and practical approaches to identification of stakeholder interests of the company. Economics, Entrepreneurship, Management, 1(1), 31-35.

Shvab, K. (2019). Choho my khochemo? Try modeli maybutn'oho na vybir. Novoe vremya [What do we want? Three models of the future to choose from]. Available at: https://nv.ua/ukr/opinion/forum-u-davosi-yakzminyuyetsya-kapitalizm-ekonomika-novini50057107.html (accessed 10 September 2021).

Trushkina, N. (2020). Upravlinnja lancjughamy postachanj $v$ koncepciji industrializaciji 4.0 [Supply chain management in the concept of industrialization 4.0]. Kyiv: National Academy of Sciences of Ukraine, Institute for the Economy of Industry. (in Ukrainian)

Trushkina, N. V., Kitrish, K. Yu., \& Shkryhun, Yu. O. (2020). Tendentsii rozvytku hlobalnykh lantsiuhiv postachan $\mathrm{v}$ umovakh COVID-19 [Trends in the development of global supply chains in the conditions of COVID-19]. Naukovyi visnyk Uzhhorodskoho natsionalnoho universytetu, 33, 82-88.

Vasjutkina, N.V.(2014). Upravlinnja stalym rozvytkom pidpryjemstv: teoretyko-metodologhichnyj aspekt [Management of sustainable development of enterprises: theoretical and methodological aspect]. Kyiv: Lira-K. (in Ukrainian)

Van Gig (1981). Prikladnaya obshchaya teoriya system. Moscow: Mir. (in Russian) 